\title{
Medicine Between Ethics and Scientific Progress: How Much Ethics Needs Medicine, how much ethics can it afford? Some Considerations from Patent Law Perspectives $^{1}$
}

\author{
JOSEPH STRAUS
}

\begin{abstract}
The progress of medicine is heavily dependent on the progress of science and technology, which in turn depend on costly and risky investment in research and development. In this contribution, based on some concrete examples, new scientific achievements are presented as basis of modern medicine and source of ethical concerns. Addressed are also the role of scientists in coping with safety in ethical concerns as regards hazards of new technologies, costs of R\&D investment in drug development and the role of patents in this context. In some detail the legal situation existing at an international and European level as regards exclusions from patentability based on reasons of ethics and morals is presented. A critical appraisal of the case law of the Court of Justice of the European Union as regards patentability of embryonic stem cells is offered.
\end{abstract}

KEYWORDS: - ethics $\cdot$ scientific progress $\cdot$ costs of R\&D $\cdot$ role of patents $\bullet$ CJEU case law

\footnotetext{
Correspondence Address: Joseph Straus, Ph. D., Professor, Max Planck Institute for Intellectual Property and Competition Law, Marstallplaty 1, 80539 Munich, Germany, email: j.straus@ip.mpg.de.
} 
J. Straus: Medicine Between Ethics and Scientific Progress: How Much Ethics Needs Medicine, how much ethics can it afford?Some considerations from patent law perspectives

The multifaceted and inseparable link between the scientific and technological progress and the progress of medicine is undisputed and not in need to be generally evidenced in a contribution whose primary focus is on the tense relationship between patents and ethics of particular relevance for medicine.

In this latter context it has to be emphasized from the outset that according to Article 53 (c) of the European Patent Convention (EPC), to which also Slovenia is a party, patents shall not be granted in respect of: "Methods for treatment of the human or animal body by surgery or therapy and diagnostic methods practised on the human or animal body."

At the same time this provision sets forth that it does not apply to: "Products, in particular substances or compositions, for the use in any of these methods."

This exclusion from patentability is based on the ethical consideration that medical doctors, but also other medical personnel involved in the treatment of humans or animals should not be impeded by patents in their professional activities. ${ }^{2}$ However, as revealed from its wording, Article 53 (c) EPC makes it also clear that pharmaceutical substances, i.e. drugs, but also instruments used in such methods, or products such as artificial heaps, knees, heart valves, stents, pacemakers, as well as prosthesis, etc., and methods for their production are eligible for patent protection. Although it is crystal clear that medicine has enormously gained particularly also from scientific and technological advances in this area, and although the complicate delimitation between patentable and nonpatentable therapeutic, surgical and diagnostic methods in practice of the European Patent Office (EPO) generates rich case law, ${ }^{3}$ this contribution will focus entirely on the area of research and development as well as patent protection of medicaments, which, as a matter of principle, are patentable. The reason for this limitation is to be seen in the fact that although the exclusion of therapeutic, surgical and diagnostic methods is ethically based, ethics in its practical application does not play a visible role. Instead, very technical and basic problems of specific patent law aspects are at the core of the case law.

\section{New scientific achievements as basis of modern medicine and source of ethical concerns}

\subsection{The case of hepatitis $\mathbf{C}$ diagnostics and therapeutics}

To adequately and in brief address this issue, one most exiting current achievement of medicine may serve as an example: For the first time medical doctors seem to be able to successfully fight the hepatitis $\mathrm{C}$ virus $(\mathrm{HCV})$ by which world-wide an estimated 185 million people have been infected. In public 
perception, but possibly also in the perception of those responsible for the health care, maybe even of medical doctors, the "magic" drug sofosbuvir, discovered by Pharmasset and developed and marketed by Gilead Sciences Corporation under the brand name "Sovaldi", is at the same time reason for enthusiastic optimism, but because of the enormous cost of therapy, also a matter of major concern and critics. $^{4}$

According to Wikipedia sofosbuvir is a compound of the first all-oral, interferonfree regimen approved for treating chronic hepatitis C. The US Food and Drug Administration (FDA) approved sofosbuvir in combination with ribavirim (RBV) for oral therapy of $\mathrm{HCV}$ genotypes 2 and 3, and for triple therapy with injected pegylated interferon (peg IFN) and RBV for treatment-naïve patients with $\mathrm{HCV}$ genotypes 1 and 4. Depending on the HCV genotypes, the treatment lasts 12 or 24 weeks. ${ }^{5}$ In the US the cure for 12 weeks costs approximately US \$ 84.000 (Ward, 2014). Interesting and symptomatic, however, seems the fact that the scientific background and the history of the preceding developments of altogether some 25 years, not to speak of their complex scientific basis, which made this revolutionary achievement possible, find practically any attention. It is seemingly not realized and understood, let alone honoured, that the dual and triple therapies for curing hepatitis $\mathrm{C}$ are just the top of a scientific and technological development, which last for many decades and laid the foundations for modern biotechnology, at whose core the recombinant DNA technology sits. ${ }^{6}$ Only thanks to the combined achievements of modern biotechnology in a research over some five years, undertaken with extreme endurance, skills and intuition, in 1987 Michael Houghton, Qui-Lim Choo and George Kuo of Chiron Corporation in California detected and identified the mysterious "none-A-none-B-hepatitis" virus, which was chased in vain world-wide by so many researchers for so long and which was responsible for so many casualties. With this discovery the researchers of Chiron laid down the foundation for HCV diagnostics and already by this have saved countless lives. For its $\mathrm{HCV}$ related inventions Chiron has been granted in excess of 100 patents in over 20 countries and had to defend them in numerous patent suits. ${ }^{7}$ In the EPO Chiron was granted a European patent for its basic invention "NANBV diagnostics" in $1993 .{ }^{8}$ However, the patent was opposed by many parties and finally granted only in $2001 .{ }^{9}$

\subsection{Responsible approach of scientists towards new technologies}

It should be added that the public at large, but also many so-called stakeholders, who are still critical and partly even hostile towards genetic engineering, gene therapy, use of human stem cells, etc., and often demonstrate open distrust towards scientists and researchers, are seemingly also not aware that it were scientists themselves, who because of their safety in ethical concerns came together more than three decades ago and consented on guidelines which were seminal for subsequent legal developments. Led by later Nobel Laureates Paul 
J. Straus: Medicine Between Ethics and Scientific Progress: How Much Ethics Needs Medicine, how much ethics can it afford?Some considerations from patent law perspectives

Berg, David Baltimore and Sydney Brenner, they in 1975 organized the famous Asilomar Conference and adopted a statement of lasting importance, which paved the way for successful continuation of genetic engineering. ${ }^{10}$ In 2008 Paul Berg impressively reminded the world of that memorable event by stating, inter alia,

"Participants agreed on the final day of the conference that research should continue, but under stringent restrictions. The recommendations formed the basis of the official US guidelines on research involving recombinant DNA, issued in July 1976. They have proved remarkably effective.

In the 33 years since Asilomar, researchers around the world have carried out countless experiments with recombinant DNA without reported incident. Many of these experiments were inconceivable in 1975, yet as far as we know, none has been a hazard to public health. Moreover, the fear among scientists that artificially moving DNA among species would have profound effects on natural processes has substantially disappeared with the discovery that such exchanges occur in nature". (Berg, 2008).

Berg, finally, raised a question also worth to be reproduced here:

"Could an Asilomar-type conference help resolve some of the controversies now confronting scientists and the public - such as over fetal tissue, embryonic stemcell research, somatic and germ-line gene therapy and the genetic modification of food crops?" (Berg, 2008)

Berg is sceptic. From Asilomar he draws the lesson that the best way to respond to concerns created by emerging knowledge or early-stage technology is that scientists from publicly funded institutions find common cause with the wider public about the best way to regulate - as early as possible. To Paul Berg's understanding, this will "simply be too late", "once scientists from corporations begin to dominate the research enterprise." (Berg, 2008).

In addition to this wise advice of Paul Berg, all involved, i.e. scientists, law makers, the public at large and many of its so-called stakeholders, should realize that the time needed from a valuable and truly break-through discovery/invention to an effective cure by doctors, as a rule, is much longer than mostly assumed, predicted and even much more than hoped for. The example of the first really curing $\mathrm{HCV}$ drug is but one. In case of somatic gene therapy, mentioned by Berg as problem loaden, the first FDA approval for a trial was in 1990, but the European Medicine Agency (EMA) only in July of 2012 recommended the marketing approval of the first genetic medicine, alipogene tiparvovec (Glybera), the first gene therapy for the treatment of an ultra-rare inherited disorder lipoprotein lipase (LPL) deficiency, which was finally approved by the European Commission in November 2012. ${ }^{11}$ It should be added that the United States Patent 
and Trademark Office (USPTO) on March 21, 1995 granted a patent to National Institutes of Health (NIH), for an invention of gene therapy technology of W. French Anderson, Michael Blaese and Steven A. Rosenberg. This patent, with extremely broad claims, which covered practically all sorts of somatic gene therapy, has been exclusively licensed to the company Genetic Therapy Inc., Gaithersburg, MD, USA. Later on this company was bought by the Swiss pharmaceutical company Sandoz AG, Basel, for 295 Million US \$. Dr. Daniel Vasella, then President of Sandoz Pharmaceuticals, declared on that occasion: "We strongly believe gene therapy will transform $21^{\text {st }}$ century medical practice. We concluded that owing that technology would be very important to Sandoz." ${ }^{12}$ Thus, it has taken again more than 20 years from the invention of the basic somatic gene therapy to the first marketable gene therapy drug. During those more than 20 years, gene therapy has suffered many setbacks. ${ }^{13}$ Novartis AG, into which Sandoz AG merged with Ciba-Geigy AG in 1996, sold Gene Therapy Inc. in 2003 to Cell Genesys Inc., because the acquired patented technology could not deliver the expected results. ${ }^{14}$ Despite the first marketing approval for a somatic gene therapy in Europe and despite reported recent advances in clinical gene therapy for a number of genetic diseases, such as Hemophilia B, chronic granulomatous disorder or, $\beta$-thalasemia, or for cancer, such as B-cell leukaemia and lymphoma, acute leukaemia and melanoma, ${ }^{15}$ predicting a broader use of gene therapy in clinical practice in the near future still remains very difficult.

From the above briefly described developments, which could easily be enriched by further examples, such as for instance the developments in the stem cell research area, ${ }^{16}$ the lesson should be learned by those responsible for funding and regulating the research at hand, as well as the commercialization of the respective research results, that not only it takes years before the span from the discovery/invention to a marketable product is mastered, or a final failure realized, but also that the ethical consternation and excitement, panic as to possible safety hazards, or for instance economic dominance, have little if any basis in the past developments. They should behave and take the responsibility for the near and also more distant future they demand from scientists and researchers.

\subsection{Early and current fruits benefitting medicine and patients}

The first and an extremely beneficial product of the recombinant DNA (rDNA) technology which received marketing approval in 1982 was human insulin. ${ }^{17}$ Given the enormous benefit, which human rDNA insulin brought for patients suffering of diabetes, it is difficult to believe how many hurdles this product and its production had to take before they could bear tangible fruits. ${ }^{18}$ In Germany the then leading pharmaceutical company, Hoechst AG, had to give up even the planned production because it was denied operating permit for a fully new and operational plant! 
J. Straus: Medicine Between Ethics and Scientific Progress: How Much Ethics Needs Medicine, how much ethics can it afford?Some considerations from patent law perspectives

With some distance, human rDNA insulin was followed by erythropoietin alpha (Epogen) for treating anemia, of particular importance for patients suffering of kidney failure, launched by Amgen Inc. in 1989, and recombinant granulocyte colony stimulating factor (GCSF - Neupogen) for chemotherapy-induced neutropenia, also launched by Amgen in 1991. Both these drugs fall in the category of growth factors, which in 2006 had sales of US \$ 14.1 billion in the USA alone. Saurabh Aggarwal (Aggarwal, 2007), has segmented the market of biotech molecules into ten categories, namely: (i) growth factors, (ii) monoclonal antibodies (mAbs), (iii) hormones (iv) cytokins, (v) fusion proteins, (vi) blood factors, (vii) recombinant vaccines, (ix) anticoagulants and (x) nucleic acids. (Aggarwal, 2007: 1097)

The empirical data collected by Aggarwal as regards the development of total sales in US market for biologic drugs (2002-2006) (Figure 1), for sales of drugs ordered into the said ten categories in 2005 and 2006 (Figure 2), and for the sales of the 18 top producers of biologics in the US in 2005 and 2006 (Figure 3) are, for simplicity reasons, reproduced below.

Figure 1: Total sales in US market for biologic drugs (2002-2006) (Aggarwal, 2007: 1097

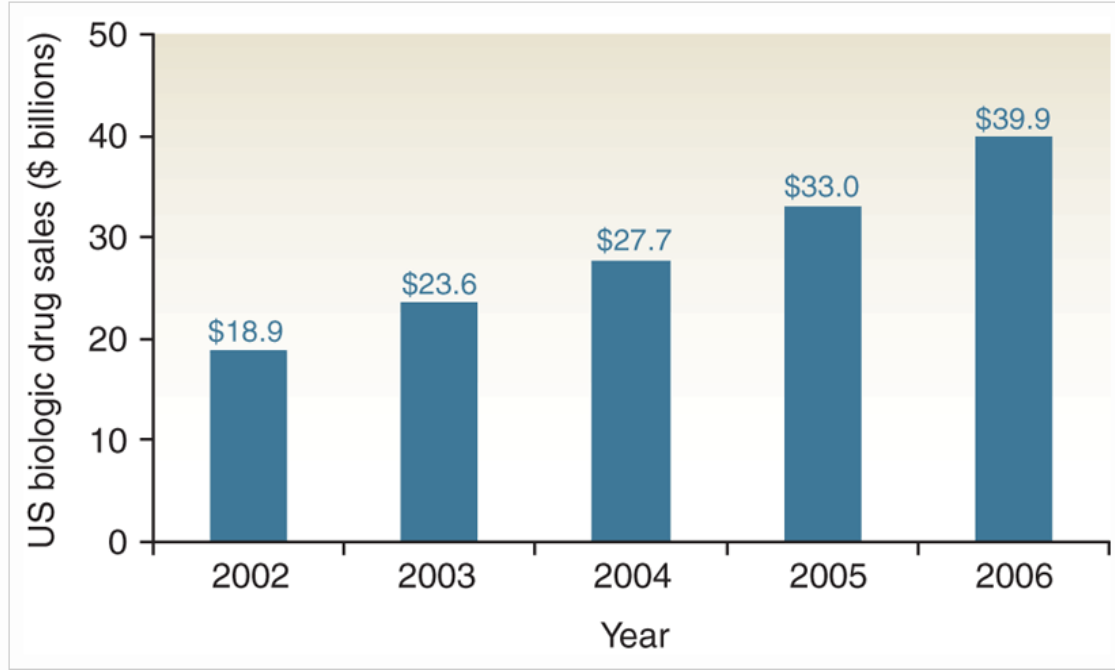


Figure 2: Top ten categories of biologic drugs in terms of US sales in 2006. Pie chart shows US sales of biologics in ten categories. The table shows the growth rates of the categories between 2005-2006. The box indicates that $\mathrm{mABs}$ have shown the largest rate of growth during that period, at 37-38\%. J\&J, Johnson \& Johnson; BMS, Bristol-Myers Squibb (Aggarwal, 2007: 1098)

\begin{tabular}{|c|c|c|c|c|}
\hline & $\$ 5.39$ & \multicolumn{2}{|c|}{$\begin{array}{l}\text { Growth factors } \\
\text { mAbs } \\
\text { Hormones } \\
\text { Cytokines } \\
\text { Fusion proteins } \\
\text { Bood factors } \\
\text { rEnzyme } \\
\text { rVaccines } \\
\text { Anticoagulants } \\
\text { Nucleic acids }\end{array}$} & \multirow[b]{2}{*}{2006 growth (\%) } \\
\hline & $\begin{array}{l}2005 \text { US sales } \\
\text { (\$ billions) }\end{array}$ & $\begin{array}{c}2006 \text { US sales } \\
\text { (\$ billions) }\end{array}$ & 2005 growth (\%) & \\
\hline Growth factors & 12.11 & 14.14 & 10 & 17 \\
\hline mAbs & 8.29 & 11.37 & 38 & 37 \\
\hline Hormones & 4.51 & 5.39 & 24 & 19 \\
\hline Cytokines & 3.11 & 3.43 & 4 & 10 \\
\hline Fusion proteins & 2.81 & 3.13 & 36 & 11 \\
\hline Blood factors & 0.74 & 0.78 & 11 & 5 \\
\hline rEnzyme & 0.58 & 0.76 & 18 & 31 \\
\hline rVaccines & 0.40 & 0.56 & -10 & 40 \\
\hline Anticoagulants & 0.34 & 0.34 & -1 & -1 \\
\hline Nucleic acids & 0.06 & 0.02 & - & - \\
\hline
\end{tabular}


J. Straus: Medicine Between Ethics and Scientific Progress: How Much Ethics Needs Medicine, how much ethics can it afford?Some considerations from patent law perspectives

Figure 3: Top 18 companies that comprised the majority of sales of biologic drugs in 2006. Pie chart shows the fraction of total biotech sales of the top 18 companies, with Amgen, Genentech and J\&J garnering the majority of the sales. The table shows annual growth rates for the top 10 companies. Boxes indicate those companies with the largest growth rates in the years analyzed. For purpose of this analysis, Rituxan US sales have been split equally between Genentech and Biogen Idec; Erbitux US sales were split 40/60 between Imclone and BMS (Aggarwal, 2007: 1099)

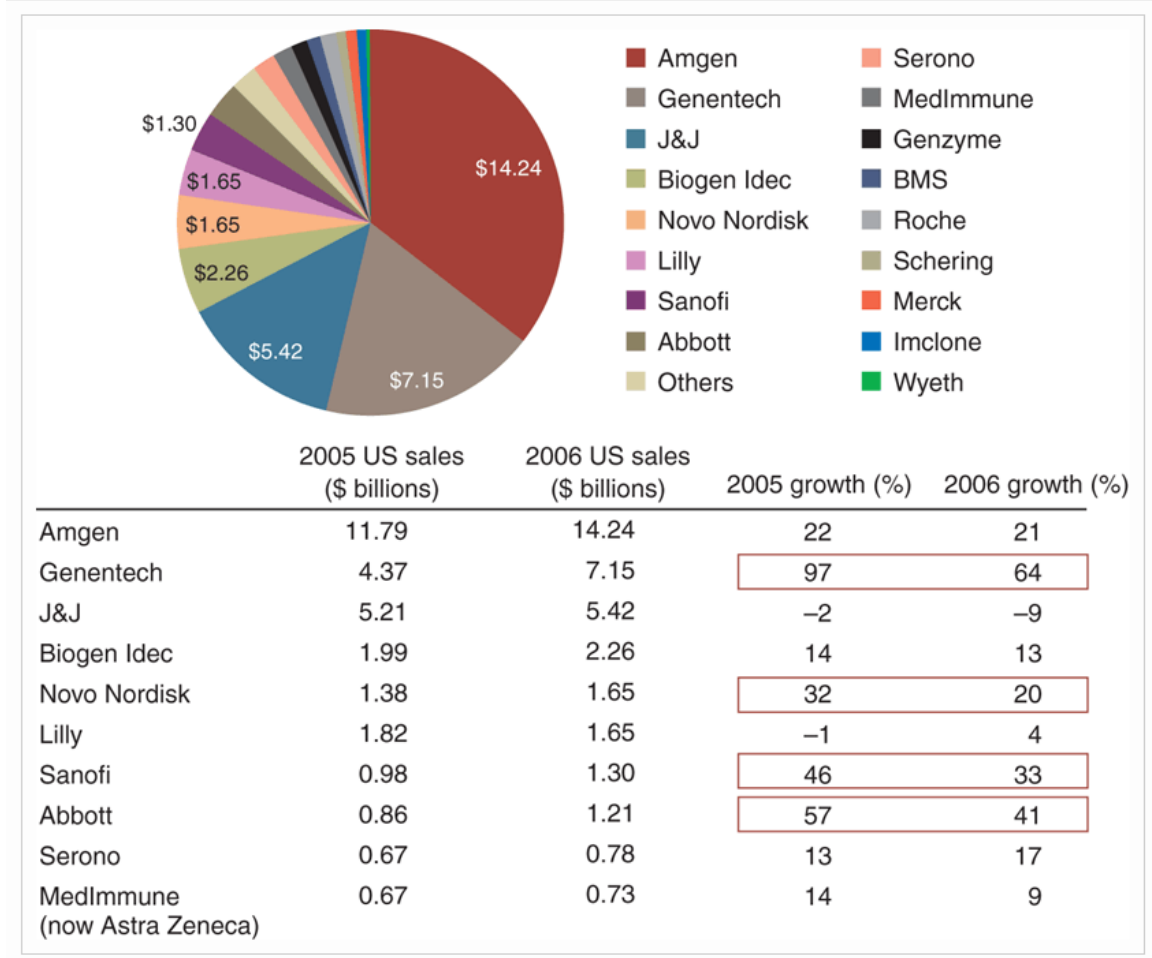

The findings of Aggarwal reveal that the US biotech drug sales were US $\$ 40$ billion in 2006 and that there has been an average growth annual rate of $20 \%$ in those sales in the period between 2001 and 2006 (Aggarwal, 2007: 1103).

In the meantime, results of research and development in the area of biotechnology and the institutions which generate those results have become a major source for new drugs receiving marketing approval. It has been observed that of 200 compounds in registration, about two thirds involved alliances with a biotech 
company, i.e. those companies have been boosting the pipelines of large pharmaceutical companies. ${ }^{19}$ The data offered by Kling for FDA new molecular entities and biologics application approvals, 1997-2011 (Figure 1) and for specific biologics approvals in 2011 (Table 1) are reproduced below.

Figure 4: FDA new molecular entities and biologics license application approvals, $1997-2011^{20}$

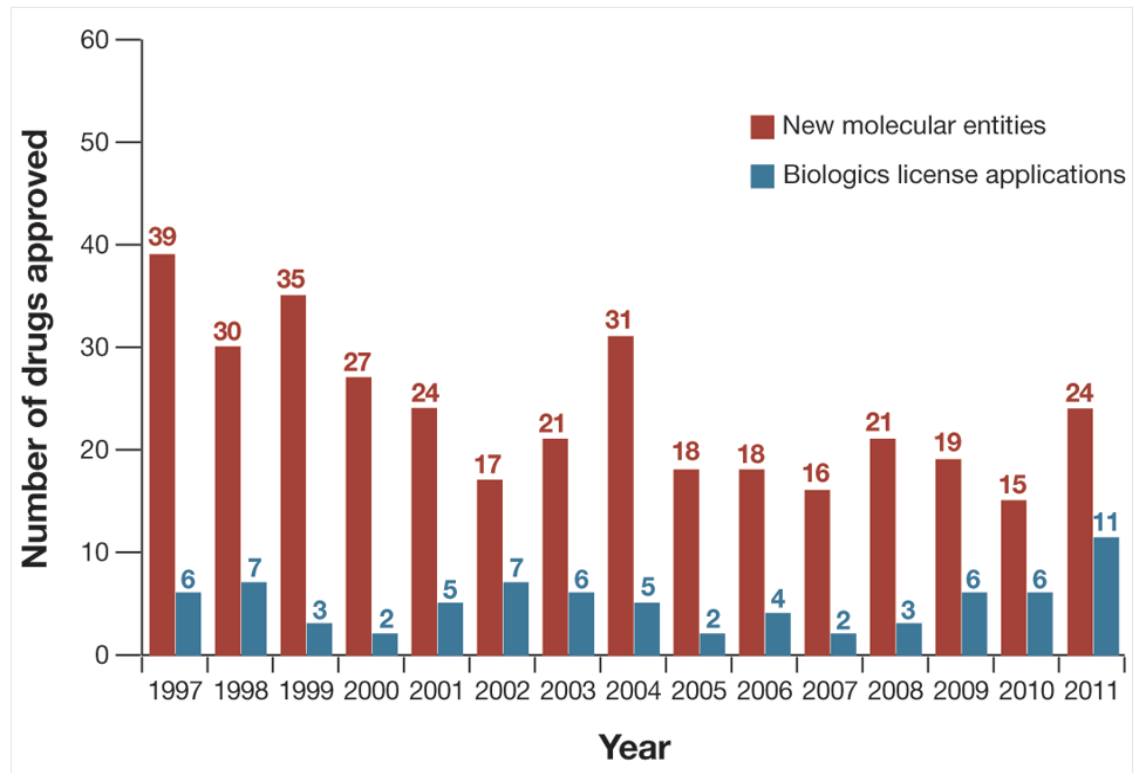


J. Straus: Medicine Between Ethics and Scientific Progress: How Much Ethics Needs Medicine, how much ethics can it afford?Some considerations from patent law perspectives

Table 1: 2011 biologics approvals ${ }^{21}$

\begin{tabular}{|c|c|c|c|c|}
\hline $\begin{array}{l}\text { Brand } \\
\text { name }\end{array}$ & Generic name & Indication & Type of drug & Developer \\
\hline Actemra & Tocilizumab & $\begin{array}{l}\text { Systemic juvenile idiopathic } \\
\text { arthritis }\end{array}$ & Humanized mAb & Genentech \\
\hline Adcetris & Brentuximab vedotin & $\begin{array}{l}\text { Hodgkin's lymphoma and } \\
\text { anaplastic large cell lymphoma }\end{array}$ & Chimeric human-mouse mAb conjugate & Seattle Genetics \\
\hline Benlysta & Belimumab & Systemic lupus erythematosus & Human mAb & $\begin{array}{l}\text { Human Genome } \\
\text { Sciences }\end{array}$ \\
\hline Erwinaze & $\begin{array}{l}\text { Asparaginase Erwinia } \\
\text { chrysanthemi }\end{array}$ & Acute lymphoblastic leukemia & Enzyme derived from Erwinia chrysanthemi & EUSA Pharma \\
\hline Eylea & Aflibercept & $\begin{array}{l}\text { Age-related macular } \\
\text { degeneration }\end{array}$ & $\begin{array}{l}\text { Fusion protein of portions of VEGF receptors } \\
1 \text { and } 2 \text { fused to the FC portion of } \operatorname{lgG}\end{array}$ & Regeneron \\
\hline Hemacord & $\begin{array}{l}\text { Hematopoietic progenitor cells } \\
\text { from human cord blood }\end{array}$ & $\begin{array}{l}\text { Bone marrow transplant; stem } \\
\text { cell transplant }\end{array}$ & $\begin{array}{l}\text { Allogeneic cord blood hematopoietic } \\
\text { progenitor cells }\end{array}$ & $\begin{array}{l}\text { New York Blood } \\
\text { Center }\end{array}$ \\
\hline laViv & Azficel-T & Nasolabial fold wrinkles & $\begin{array}{l}\text { Autologous cellular product consisting of } \\
\text { patient's collagen-producing fibroblasts }\end{array}$ & Fibrocell Science \\
\hline Nulojix & Belatacept & Transplant rejection & $\begin{array}{l}\text { Fusion protein of FC fragment of human IgG1 } \\
\text { linked to the extracellular domain of CTLA-4 }\end{array}$ & $\begin{array}{l}\text { Bristol-Meyers } \\
\text { Squibb }\end{array}$ \\
\hline Soliris & Eculizumab & $\begin{array}{l}\text { Atypical hemolytic uremic } \\
\text { syndrome }\end{array}$ & Humanized mAb & Alexion \\
\hline Sylatron & Peginterferon alfa- $2 b$ & Melanoma & $\begin{array}{l}\text { Conjugate of recombinant alfa- } 2 \mathrm{~b} \text { interferon } \\
\text { with monomethoxy polyethylene glycol }\end{array}$ & Merck \\
\hline Yervoy & Ipilimumab & Melanoma & Humanized mAb & $\begin{array}{l}\text { Bristol-Myers } \\
\text { Squibb }\end{array}$ \\
\hline
\end{tabular}

\subsection{The costs of drug research and development}

Although the costs for research and development (R\&D) of a new drug may vary and although the exact amount of money necessary to invest is not easy to determine and is also often contested, no doubt exists that investment in drug R\&D is not only extremely high but also extremely risky. This is acknowledged even by critical economist ${ }^{22}$ and science administrators. ${ }^{23}$ In the context of this contribution it should suffice to observe that the average cost of R\&D until FDA marketing approval for a new drug is around US \$ 800 million in the USA, and the time needed, including clinical trials, between 10 and 15 years. In this calculation also the high share of failures is and has to be taken into account: Only $8 \%$ of drugs entering Phase 1 of clinical trials are, eventually, approved. Moreover, some $4 \%$ of the already approved drugs are later on withdrawn from the market, which reduces the income and increases the costs involved in product liability.$^{24}$ Finally, some US $\$ 140$ million are on average the R\&D costs incurred after the FDA approval. ${ }^{25}$ 
In view of such high risk investment in $R \& D$ in drugs it is generally accepted that an adequate protection of pharmaceuticals against copying, which is as a rule, relatively cheap, is needed. ${ }^{26}$ In this context, it could not be emphasized enough that all reported successful drugs referred to above (No. 2.3) from which patients and pharmaceutical and biotech companies greatly benefit, have been patented world-wide.

\subsection{The complex relationship between ethics in regulatory provisions and patent eligibility}

Because this contribution is focused primarily on aspects of particular interest to medicine, and also because the readership of this book presumably will not be patent lawyers, it seems proper to at the very outset recall Recital 14 of the EU Biotechnology Directive, ${ }^{27}$ which restates and endorses one of the hallowed principles of patent law as follows:

"...a patent for invention does not authorize the holder to implement that invention, but merely entitles him to prohibit third parties from exploiting it for industrial and commercial purposes... consequently, substantive patent law cannot serve to replace or render superfluous national, European or international law which may impose restrictions or prohibitions or which concerns the monitoring of research and of the use or commercialization of its results, notably from the point of view of the requirements of public health, safety, environmental protection, animal welfare, the preservation of genetic diversity and compliance with certain ethical standards."

In other words, neither the European Patent Office nor national patent offices "allow" anything, and have no business to do so. The patents they grant do not include any kind of permission for the holder to use the invention, even if it does not collide with any prohibitions on patenting and clearly fulfills all the requirements for patentability. If the exploitation of the invention breaches legal prohibitions, even the patentee cannot use it. ${ }^{28}$

After this general statement of principles, it should be added that patents, as other intellectual property rights, are generally understood as an instrument of economic policy providing incentives for and rewarding a broad range of useful human activity. Despite this prevailing economic rationale, the roots of, the justification for, and some limitations of exploitation are reasoned ethically. Traditionally, ethical aspects in intellectual property rights have been discussed in the broad context of justification of these rights. Lockean theory of natural rights to the fruits of own's labour, the doctrine of intellectual property, as well as Hegel's personality justification suggesting that the best way of progressing science and arts is to protect scientists and artists from theft, so as to become the basis for learning by others, are such examples. (Straus, 2001). 
J. Straus: Medicine Between Ethics and Scientific Progress: How Much Ethics Needs Medicine, how much ethics can it afford?Some considerations from patent law perspectives

Consequently, patent law, as other laws, is subject to barriers inherent in the legal system, set by the Constitution, by public policy and by morals. These barriers exist in most countries, in legal orders of regional organizations of states, such as the European Union, and international regional multinational treaties, such as the 1973 adopted EPC. As an example, Article 53 (a) of the EPC excludes from patentability inventions the commercial exploitation of which would be contrary to ordre public or morality. These two general clauses were understood to constitute the necessary gates of entry for overriding social and ethical considerations into the patent law system, which is otherwise neutral in its judgement and entirely devoted to the technological appreciation of inventions. ${ }^{29}$

Under Article 27 (2) of the Agreement on Trade Related Aspects of Intellectual Property Rights (TRIPS) of 1994/1995 ${ }^{30}$

"Members may exclude from patentability inventions, the prevention within their territory of the commercial exploitation of which is necessary to protect ordre public or morality, including to protect human, animal or plant life or health or to avoid serious prejudice to the environment, provided that such exclusion is not made merely because the exploitation is prohibited by their law."

Article 27 (2) TRIPS, thus, makes it clear that the Agreement itself does not impose the exclusion from patentability of inventions the commercial exploitation of which would contradict ordre public or morality, but only permits WTO Member States to provide for such exclusions in their national or regional legal instruments. However, the TRIPS Agreement makes such exclusions dependent on certain conditions. Consequently, the possibility of WTO Member States to exclude certain subject matter from patentability based on considerations of ordre public or morality is limited under this controlling mandatory international test standard. ${ }^{31}$

\subsubsection{Ordre public}

By adopting the notion of ordre public instead of "public order" or "public interest", the TRIPS Agreement adopted a more narrow standard. ${ }^{32}$ Thereunder the notion of ordre public comprises only the "major principles of the legal order," such as the inviolability of human dignity and the right to life, physical integrity, and personal freedom, as for instance laid down in Article 2 (2) of the Basic Law (Constitution) of the Federal Republic of Germany. ${ }^{33}$ Such principles are not necessarily infringed solely because exploitation of the invention is prohibited by law or administrative regulations. The European patent law harmonizers decided in favour of this narrow standard because it was not necessarily in the general interest to deny patentability in all cases where the exploitation of the invention concerned was prohibited, for instance under a foodstuff law allowing certain additives. The inventor of a new additive with possibly less harmful effects should 
indeed have the possibility of obtaining a patent since it is possible that the prohibition of exploitation may subsequently be removed. Or in more modern terms, even if the somatic cell gene therapy, or the use of human embryonic stem cells for curing Parkinson's disease may be prohibited for safety considerations today, which could be cleared by further scientific achievements and developments related to transfer vectors, etc., in say two or three or possibly only in five years, resulting in subsequent removal of those prohibitions, why should an inventor of suitable stem cells, or gene constructs respectively, not be granted a patent, but left empty handed and others allowed to use his/her invention for free after the removal of the ban. This would not only be unfair but also counterproductive in terms of providing incentives for the necessary investment into innovation. In the chosen construct account is taken of the fundamental consideration that a patent does not afford its owner a positive right to use, but solely a right to prohibit. ${ }^{34}$

Despite considerable consensus of states on what constitutes the fundamentals of a given society, thus its ordre public, the TRIPS Agreement has, for the first time in the history introduced some mandatory standards, i.e. imposing on WTO members that laws which

"protect human, animal or plant life or health or to avoid serious prejudice to the environment,"

in principle form part of ordre public.

The wording of Article 27 (2) of the TRIPS Agreement, however, makes it also clear that WTO Members may invoke the exclusion of patentability on grounds of ordre public or morality only under certain conditions.

Firstly, and most importantly, exclusion from patentability of a specific invention is only allowed, if the commercial exploitation of that invention is prohibited in the territory of the respective Member. ${ }^{35}$ As Correa has observed, "The obvious purpose of this condition is to prevent a situation in which an invention is declared non-patentable but its commercialization is permitted." (Correa, 2007: 291). As further observed by Pires de Carvalho, the phrase "necessary to protect ordre public or morality" requires that a causal connection exists between the measure taken (exclusion from patentability) and the effect sought (protection of ordre public or morality) (Pires de Carvalho, 2010: 289). According to Pires de Carvalho (Pires de Carvalho, 2010: 209-210), the application of Article 27 (2) TRIPS requires a two-step test based on two criteria available in the legal system of the WTO. As regards the necessity of excluding an invention from commercial exploitation, WTO Members must observe Article 2 (2) of the WTO Agreement on the Application of Sanitary or Phytosanitary Measures (the "SPS" Agreement), which sets forth that: 
J. Straus: Medicine Between Ethics and Scientific Progress: How Much Ethics Needs Medicine, how much ethics can it afford?Some considerations from patent law perspectives

"Members shall ensure that any sanitary or phytosanitary measure is applied only to the extent necessary to protect human, animal or plant, is based on scientific principles and is not maintained without sufficient scientific evidence." ${ }^{36}$

Only after that had been established, and evidence found that the exclusion of an invention from commercial exploitation contributes indeed to the protection of ordre public or morality, the second test has to be undertaken, namely whether the necessity exists to exclude an invention from patentability in order to prevent its commercial exploitation. For this second step, the yardstick, according to Pires de Carvalho is Article 2 of the WTO Agreement on Technical Barriers, ${ }^{37}$ which requires that

"Members shall ensure that technical regulations are not prepared, adopted or applied with a view to or with the effect of creating unnecessary obstacles to international trade. For this purpose, technical regulations shall not be more traderestrictive than necessary to fulfil a legitimate objective..." (paragraph 2),

and that

"Technical regulations shall not be maintained if the [...] objectives can be addressed in a less trade-restrictive manner." (paragraph 3).

From the above Pires de Carvalho summarizes:

"In other words, if the objective of excluding the commercial exploitation of inventions in a certain field of technology can be achieved in a way that does not require excluding inventions from patentability, then that way should always be preferred." ${ }^{38}$

Finally, the last part of Article 27 (2) TRIPS, which reads:

"...provided that such exclusion ${ }^{39}$ is not made merely because the exploitation is prohibited by domestic law."

requires that a Member may not base the exclusion from patentability on legal prohibitions unrelated to ordre public or morality. ${ }^{40}$ In other words, whereas the prohibition of commercial exploitation is a basic precondition for the exclusion, it in itself is not sufficient, if it is not based on reasons routed in ordre public or morality. ${ }^{41}$ This reflects the genuine understanding of the European ${ }^{42}$ and now also the global international law maker, that inventors may not be deprived of their rights if the exploitation of the invention at issue is prohibited by laws or regulations, which do not form part of the ordre public, i.e. "major principles of the legal order". He or she, the inventor, should enjoy the fruits of their creative 
efforts if the prohibition of exploitation of the invention is subsequently removed, e.g. as a result of new scientific findings, etc. ${ }^{43}$ Pires de Carvalho, therefore, draws from Article 27 (2) TRIPS the practical consequence for the work of patent examiners, namely that they have, first, to check whether the law prohibits the commercialization of the claimed invention. If that is not the case, the usual patentability requirements are to be examined and the decision taken according to the reached results. ${ }^{44}$ Arguing that the exploitation of an invention could be contrary to ordre public or morality even if such exploitation were allowed by specific laws, ${ }^{45}$ implies the assertion that the laws at stake must be unconstitutional and/or immoral. ${ }^{46}$

\subsubsection{Morality}

Article 27 (2) TRIPS enumerates ordre public or morality as two seemingly independent standards for values, the protection of which allows, under the conditions discussed above, WTO Members to exclude from patentability inventions the commercial exploitation of which would violate either or both of them. The leading commentaries on TRIPS are quite short as regards the notion of morality. Gervais observes that morality is a different concept as compared with ordre public and that "it seems to correspond to the French concept of 'bonnes mœurs', further that 'it naturally depends to a certain degree on particular culture of a country or region.'" 47 Correa, after having observed that there is no internationally accepted interpretation of the morality concept,${ }^{48}$ states that

"Morality judgements depend on the values prevailing in a particular society at particular time. Such values are not the same in different cultures and countries and change over time. Like 'ordre public', morality is a vague and evolutive concept ${ }^{49}$ and their content will be dependent on national perception by patent offices or judges." ${ }^{50}$

In the German legal doctrine, Rüdiger Rogge emphasizes that the reference to the notion of morality was necessary to directionally regulate specifically not foreseeable variety of factual constellations. However, Rogge also points to the danger of such provisions being applied in a very subjective, eventually discretionary manner resulting in a disproportional loss of legal certainty. ${ }^{51}$ It is, therefore, following Rogge, necessary to narrow down this provision according to its purpose and context. The notion of morality, which in German translation reads as "gute Sitten", i.e. "bonnes mœurs", refers, on the one hand to extra-legal ("außerrechtliche") principles, but on the other hand forms part of the legal order. Consequently, what is at hand, is to put in effect in a specific case the value standards ("Wertmaßstäbe"), which are anchored in the general legal order. A potential violation of the morality standard must be of such weight that it would justify an exception of the fundamentally existing claim or right to a patent. Prohibitions which are not anchored in statutory provisions, therefore, have to be 
J. Straus: Medicine Between Ethics and Scientific Progress: How Much Ethics Needs Medicine, how much ethics can it afford?Some considerations from patent law perspectives

essentially generally recognized as obligatory and have to be limited to elementary rules. $^{52}$

Apart from a number of Recitals of the EU Biotechnology Directive which extensively refer to ordre public or morality, ${ }^{53}$ the wording of the Directive itself reflects the respective considerations in two articles. First, Article 5 (1) states that

"The human body, at the various stages of its formation and development and the simple discovery of one of its elements, including the sequence or partial sequences of a gene, cannot constitute patentable inventions."

Whereas the exclusion from patentability of the "simple discovery" of elements of the human body, including the gene sequences, addresses the delimitation between non-patentable discoveries, as such, and inventions, ${ }^{54}$ the exclusion of the "human body, at various stages of its formation and development", is clearly aimed at guaranteeing human dignity and integrity. ${ }^{55}$

Directly addressed are ordre public and morality in Article 6 of the Directive. Its first paragraph sets forth that

"Inventions shall be considered unpatentable where their commercial exploitation would be contrary to ordre public or morality; however, exploitation shall not be deemed to be so contrary merely because it is prohibited by law or regulation."

This provision according to the established case law of the European Court of Justice (ECJ) - now Court of the European Union (CJEU) allows the administrative authorities and courts of the Member States a wide discretion in applying the exclusion from patentability of inventions, which is necessary to take account of the particular difficulties to which the use of certain patents may give rise in the social and cultural context of each Member State, a context which the national legislative, administrative and court authorities are better placed to understand than are the Community authorities. ${ }^{56}$ However, as it is explicitly pointed out in the second paragraph of Article 6, no such discretion exists for the Member States as regards the patentability of four specifically identified categories of inventions. ${ }^{57}$ Article 6 (2) reads as follows:

"On the basis of paragraph 1, the following, in particular, shall be considered unpatentable:

(a) processes for cloning human beings;

(b) processes for modifying the germ line genetic identity of human beings;

(c) uses of human embryos for industrial or commercial purposes; 
(d) processes for modifying the genetic identity of animals which are likely to cause them suffering without any substantial medical benefit to man or animal, and also animals resulting from such processes."

\subsubsection{The Brüstle v. Greenpeace Case}

Based on a referral of the German Federal Supreme Court (BGH) of 17 December $2009^{58}$ in which the Court of the European Union was asked, inter alia, to ascertain whether the human embryonic stem cells which served as base material for the process patented in the case at issue, constitute "embryos" within the meaning of Article 6 (2) (c) of the Directive and whether the organisms of which those human embryonic stem cells can be obtained constitute "human embryos" within the meaning of that article, although they are not totipotent cells, but only pluripotent cells obtained from embryos at the blastocyst stage, the CJEU, for the first time, had to interpret Article 6 (2) of the Directive. ${ }^{59}$ Specifically, the German Federal Supreme Court asked (1) what is meant by the term "human embryos" in Article 6 (2) (c), ${ }^{60}(2)$ what is meant by the expression "use of human embryos for industrial or commercial purposes"? Does it include also use for the purposes of scientific research? And (3) is technical teaching to be considered unpatentable pursuant to Article 6 (2) (c) of the Directive even if the use of human embryos does not form part of the technical teaching claimed with the patent, but is a necessary precondition for the application of that teaching, either because the patent concerns a product whose production necessitates the prior destruction of human embryos, or because the patent concerns a process for which such a product is needed as base material. ${ }^{61}$

In addition to these explicit questions, the German Federal Supreme Court drew attention to the fact that a prohibition of patentability, which also covers acts of exploitation, which according to the laws of some Member States were allowed, could be incompatible with Article 27 (2) of the TRIPS Agreement. The Court pointed out that according to the latter rule, which is mentioned in Recital 36 of the Directive and whose second paragraph corresponds with Article 6 (1) of the Directive, inventions can be excluded from patentability only, when the prevention of their industrial exploitation is necessary to protect ordre public or morality. An interpretation which would force Member States to deny patent protection despite the fact that the exploitation of the invention at hand, according to the national legal order, would not be contrary to morality or ordre public, may contradict also Article 1 (2) of the Directive, emphasizing that the Directive "shall be without prejudice to the obligations of the Member States" in particular under the TRIPS Agreement. ${ }^{62}$

Since the CJEU in the Brüstle v. Greenpeace case limited itself to replying to questions raised by the German Federal Supreme Court and saw no necessity to interpret either the notion of "ordre public" or that of "morality" anew in an 
J. Straus: Medicine Between Ethics and Scientific Progress: How Much Ethics Needs Medicine, how much ethics can it afford?Some considerations from patent law perspectives

European context beyond its former case law, it should suffice also here to focus only on some aspects of this much discussed judgment.63 The Court justified its narrow approach by the fact that under Article 6 (2) of the Directive, by the decision of the legislator, the "use of human embryos for industrial or commercial purposes" by all means is contrary to ordre public or morality. As regards the notion of "human embryo", which the Directive does not define and for which no European consensus exists, the CJEU, contrary to the European Court of Human Rights (ECHR) ${ }^{64}$ found it necessary to, for the purposes of the application of the Directive, in this regard designate an autonomous concept of European Union law which must be interpreted in a uniform manner throughout the territory of the Union. ${ }^{65}$ The Court went on by stating that the lack of a uniform definition of the concept of human embryo would create a risk of the authors of certain biotechnological inventions being tempted to seek their patentability in the Member States which have the narrowest concept of human embryo and are accordingly the most liberal as regards possible patentability, because those inventions would not be patentable in the other Member States. Such a situation, according to the Court, would adversely affect the smooth functioning of the internal market which was the aim of the Directive. ${ }^{66}$ Without examining the drafting history of the Directive, which suggests a different understanding of Article 6 (2) (c) of the Directive, ${ }^{67}$ the Court deduced from the Recitals in connection with Article 5 (1) of the Directive that the context and aim of the Directive thus show that the European Union legislature intended to exclude any possibility of patentability where respect for human dignity could thereby be affected. Therefore the concept of "human embryo" within the meaning of Article 6 (2) (c) of the Directive must be understood in a wide sense, namely as any human ovum, as soon as fertilized, if that fertilization is such as to commence the process of development of a human body. ${ }^{68}$ Moreover, the Court added, that this classification must also apply to a non-fertilized human ovum into which the cell nucleus from a mature human cell has been transplanted and a non-fertilized human ovum whose division and further development have been stimulated by parthenogenesis. The Court reasoned that latter qualification by the capability of those cells "of commencing the process of development of a human being just as an embryo created by fertilization of an ovum can do so." 69

As regards the second question, the Court simply held that although the aim of scientific research must be distinguished from industrial or commercial purposes, the use of human embryos for the purpose of research which constitutes the subject-matter of a patent application cannot be separated from the patent itself and the rights attaching to it. ${ }^{70}$ Consequently, according to the holding of the Court, the exclusion from patentability concerning the use of human embryos for industrial or commercial purposes in Article 6 (2) (c) of the Directive also covers the use for purposes of scientific research. ${ }^{71}$ 
Finally, the Court of the European Union declared also an invention as unpatentable, even if the claims of the patent do not concern the use of human embryos, where the implementation of the invention requires the destruction of human embryos. In this context the Court emphasized that also in such a case, there is use of human embryos within the meaning of Article 6 (2) (c) of the Directive and that the fact that destruction may occur at a stage long before implementation of the invention, as in the case of the production of embryonic stem cells from a lineage of stem cells the mere production of which implied the destruction of human embryos, were irrelevant. ${ }^{72}$ The Court reasoned this interpretation by stating that "not to include in the scope of the exclusion from patentability set out in Article 6 (2) (c) of the Directive technical teaching claimed, as the ground that it does not refer to the use, implying their prior destruction of human embryos would make the provision concerned redundant by allowing a patent applicant to avoid its application by skilful drafting of the claim. ${ }^{73}$

In the context of this contribution there is neither space nor necessity for arguing about the definition of the notion "human embryo" as laid down by the Court of Justice of the European Union, nor about its holding that the use of human embryos for scientific research is also covered by Article 6 (2) (c) of the Directive, thus, equating research in human embryonic pluripotent stem cells, which were legally, meaning in accordance with the competent law in force, generated from (supernumerary) embryos, with "use of human embryos for industrial or commercial purposes." However, the necessity exists to specifically observe, on the one hand, that the CJEU by declaring the destruction of human embryos from which, like in the Brüstle case, the human pluripotent embryonic stem cells were (legally) generated as part of the technical teaching at hand in the application, although it has neither been claimed, nor described, nor is it necessary for performing/implementing the invention as claimed, has obviously adopted a very contestable approach, actually not in line with its former case law. ${ }^{74}$ On the other hand, the Court remained entirely silent, and by doing so, fully ignoring the consideration of the German Federal Supreme Court that such an interpretation could contradict the binding standard of Article 27 (2) of the TRIPS Agreement and at the same time disregard the rule of Article 1 (2) of the Directive, how the fact is to be judged that a number of Member States allow commercial exploitation of products generated from human embryonic stem cells in their national laws. In fact, not only national laws of a number of Member States, but also the Directive 2004/23/EC of the European Parliament and of the Council of 31 March 2004 on setting standards of quality and safety for the donation, procurement, testing, processing, preservation, storage and distribution of human tissues and cells, ${ }^{75}$ according to its Recital 7 applies to "tissues and cells including hematopoietic peripheral blood, umbilical-cord (blood) and bone-marrow stem cells, reproductive cells (eggs, sperm), foetal tissues and adult and embryonic stem cells". Moreover, according to Article 1 (1) of this Directive, it applies to donations, procurement, testing, processing, preservation, storage and distribution 
J. Straus: Medicine Between Ethics and Scientific Progress: How Much Ethics Needs Medicine, how much ethics can it afford?Some considerations from patent law perspectives

of human tissues and cells intended for human applications and of manufactured products derived from human tissues and cells intended for human applications. Thus, also to products manufactured from human embryonic pluripotent stem cells. Finally, mention should also be made, in the context at hand, of the Regulation (EC) No. 1394/2007 of the European Parliament and of the Council of 13 November 2007 on advanced therapy medical products and amending Directive 2001/83/EC and Regulation (EC) No. 726/2004. ${ }^{76}$ As pointed out in Recital 7, this regulation of advanced therapy medical products at Community Level should not interfere with decisions made by Member States on whether to allow the use of any specific type of human cells, such as embryonic stem cells, or animal cells. It should also not affect the application of national legislation prohibiting or restricting the sale, supply or use of medicinal products, containing, consisting of or derived from these cells. In other words, at the European Union's level, the commercial exploitation of, for instance medical products derived from human embryonic stem cells, which were generated from destructed human embryos, is, in principle, allowed. ${ }^{77}$

In fact, products derived from human embryonic stem cell lines are in the meantime traded in the markets of the Member States of the European Union. As an example the "Product Selection Guide" of the US company Millipor advertises so-called ENStem- $\mathrm{A}^{\mathrm{TM}}$ Human Neural Progenitor Cells derived from NIHapproved H 9 Human Embryonic Stem Cells (hESCs), for research use only. ${ }^{78}$ Under the given legal order of the European Union, in principle, allowing the commercial exploitation of human embryonic pluripotent stem cells, meaning stem cells the base material of which, to use the language of the CJEU, obtained by destruction of human embryos, ${ }^{79}$ but at the same time excluding such products from patent protection, based on the consideration that such exclusion is necessary to prevent their commercial exploitation which would be contrary to ordre public or morality, is certainly not covered by Article 27 (2) TRIPS. The German Federal Supreme Court correctly made that point, although still "veiled" in a question. Should the CJEU Brüstle v. Greenpeace holdings endure, ${ }^{80}$ the EU legislator will either have to prohibit all commercialization of any products originating in human embryonic stem cells, meaning generated from destructed human embryos, or undertake changes in the EU Biotech Directive, which will make an interpretation impossible according to which the notion of an invention, meaning of a technical teaching how to solve a problem by technical means, is entirely independent of the claims and even of the description, but covers not only the base material, but also its generation, no matter how legal that generation may have been. If neither changes will be undertaken, the European Union and its Member States allowing the respective commercialization could well be brought before the Dispute Settlement Body of WTO, for not complying with Article 27 (2) TRIPS. ${ }^{81}$ 


\section{Some final thoughts}

Linking patent eligibility of inventions to ordre public and/or morality implies a complicate and tense relationship. Although to a different degree, both, ordre public and morality are subject to unpredictable, or at least difficult to predict evolutionary changes, as a consequence of scientific and technological developments as well as changes of public acceptance. Granting of patents, which do not confer on their owners any positive license to exploit the patented invention, but only an exclusive right to use it in compliance with regulatory provisions and rights of third parties, and whose main macro-economic aim is to provide sufficient incentives for investment into risky research and development, hopefully leading to badly needed innovation and, via market success, to reward of inventors and innovators, should not be made dependent on rules and principles, which are more or less short lived, more or less broadly accepted by the public at large and, by all means, nearly without exception, subject to unpredictable evolutionary changes. Developments of science, technology and industry in the USA and in Europe reveal the higher efficiency of the USapproach whose statutes and case law have not established such a link over that adopted in Europe. This is true not only in terms of scientific, technological and economic achievements, as demonstrated in the area of biotechnology, but even in terms of ethics and morals, and last but not least, in terms of compliance with the mandatory international standard anchored in Article 27 (2) of the TRIPS Agreement. This is best demonstrated by the deplorable, actually not acceptable consequences of the Judgment of the Court of Justice of the European Union in the Brüstle v. Greenpeace case, namely that under the pretext to protect human dignity, the Brüslte invention remained unprotected, but at the same time stem cell lines of the type used by Brüstle for his invention, can in a great number of the EU Member States be legally generated from supernumerary human embryos, the products of the Brüstle type invention can be commercialized in most of the EU Member States, and, the Brüstle invention can be freely copied EU-wide. This does not appear to be either in line with ethics and morals, nor with the basic mission of the patent system, nor with Article 27 (2) of the TRIPS Agreement. It certainly does not serve the rightly understood macro-economic interests of the European Union and its citizens.

The European Academic Community is anxious that CJEU case law could not have only negative legal consequences, but also negative consequences for funding stem cell research at the European Union level. In fact, the Committee on Legal Affairs of the European Parliament has already undertaken an attempt to stop funding research in human embryonic stem cells with the argument, that because no patents can be obtained for research results in this area, there should also be no funding for the respective research at the EU level. ${ }^{82}$ In a number of statements the Federation of European Academies of Sciences and Humanities 
J. Straus: Medicine Between Ethics and Scientific Progress: How Much Ethics Needs Medicine, how much ethics can it afford?Some considerations from patent law perspectives

(ALLEA) has expressed its respective concerns and made critical comments on the prevailing situation (ALLEA, 2012; ALLEA, 2013).

Medicine, including research in new drugs, certainly needs ethics. However, it needs and can afford only an objective ethics which prudently takes responsibility for the future well-being of patients and does not constitute an irresponsible obstacle for further progress of medicine.

\section{Notes}

${ }^{1}$ Parts 3.2.1 ss. of this contribution are partly reproduced from (Straus, 2013)

${ }^{2}$ For more cf., e.g. (Benkard (K.-J. Melullis), 2012:438 (marginal note 99)). For the sake of clarity, it should be added here that in the USA such methods are patentable, however, medical practitioners performing patented medical or surgical procedure on a body do not commit patent infringement according to the special provision of 35 U.S. Code (Patents Act), $\S 287$ (c).

${ }^{3}$ This is evidenced by an extremely high number of decisions handed down by the Boards of Appeal of the EPO (cf., e.g. (Benkard (K.-J. Melullis), 2013: 438-452, op.cit. footnote 2, marginal notes 99-136).

${ }^{4}$ Cf. e.g. (Stollorz, 2014; Hill and Cooke, 2014:141; Ward, 2014:5).

${ }^{5} \mathrm{http} / / /$ en.Wikipedia.org/wiki/sofosbuvir (last visited 01.08.2014).

${ }^{6}$ For a very condensed description of the respective developments, (see Straus, 1985:2242), with specific references to patents granted in the US and in the EPO for inventions in this specific area.

${ }^{7}$ Cf. (BW Health Wire, 1998)

${ }^{8}$ Mention of the grant on 15.12.1993, Bulletin 1993/50.

9 EP 0318216 B2, date of filing 18.11.1988, date of publication and mention of the opposition decision 29.08.2001, Bulletin 2001/35.

${ }^{10} \mathrm{Cf}$. (Berg et al., 1975). At the core of the detailed recommendations of that statement was the consensus that recombinant DNA research should be performed only on deactivated bacteria, not viable outside laboratories.

${ }^{11}$ Cf. (Moran, 2012; Gallagher, 2012; Whalen, 2012).

${ }^{12}$ Cf. for more (Straus, 1996b); same (Straus, 2000):112-117, with further references).

${ }^{13}$ Cf., e.g. (Kaiser, 2007; Ledford, 2007).

${ }^{14}$ In 2009 Cell Genesys Inc. merged with BioSante Pharmaceuticals Inc. (BPAX) and was worth some US \$ 38 million (cf. http://www.biospace.com/News/biosante-pharmaceuticalsinc-to-buy-cell-genesys/14...;

and http://www.businesswire.com/news/home/20090903005210/en/BioSante-PharmaceuticalsCell-Genesys-Announce-September-30).

${ }^{15} \mathrm{Cf}$. (Seymour and Thrasher, 2012).

16 Research in human stem cells is without doubt the area surrounded by most ethical concerns and objections, but also an area harboring most hopes for the progress of medicine, still some distance away from being fulfilled. It is also an area in which new ways were found to generate pluripotent human stem cells without using as source human embryos. Here reference should only be made to (C. Holden and Vogel, 2008: 560-563). As an example for the volatile policy in regulating embryonic stem cell research the laws in France could be referred to cf. (Drabiak-Syed, 2013).

${ }^{17}$ Cf. (Johnson, 1983). 
18 I.S. Johnson, who was Vice-President of Research of Lilly Research Laboratories, a division of Eli Lilly and Company, Indianapolis, the first producer of rDNA human insulin, also reported on many regulatory problems, as well as safety and other concerns of the public at large, but also the regulatory bodies, before this product could reach the market (Johnson, 1983).

${ }^{19}$ Cf. (Kling, 2012:131) referring to Deloitts's Hudes.

${ }^{20}$ (Kling, 2012:128).

${ }^{21}$ (Kling, 2012:130). For the most recent empirical data as regards the sales in the US market for biologic drugs, the top categories of biologic drugs in terms of US sales, the leading drug companies as well as the best selling drugs, cf. (Aggarwal, 2014).

${ }^{22}$ Cf., e.g. (Mansfield, 1986).

${ }^{23}$ Cf. (Cohen and Merrill, 2003:3).

${ }^{24} \mathrm{Cf}$. (Caskey, 2007: 2 with further references).

${ }^{25}$ Cf. (Di Masi, Hansen and Grabowski, 2003:173).

${ }^{26}$ This is expressly admitted also by (Landes and Posner, 2003: 313).

${ }^{27}$ Directive 98/44/EC of the European Parliament of the Council of 06.07.1998 on The Legal Protection of Biotechnological Inventions, OJ EC No. L 213/13 of 30.07.98.

${ }^{28}$ Cf. (Straus, 2000a).

${ }^{29}$ Cf. (Beier and Straus, 1986: 448).

30 TRIPS Agreement sets forth international standards for intellectual property rights binding all members of the World Trade Organization (WTO) (cf. generally on TRIPS, WTO and their impact on world economy (Straus, 2012).

${ }^{31}$ Cf. (Rogge, 1998: 303).

${ }^{32}$ Cf. (Gervais, 2003: 222).

${ }^{33}$ Cf. German Federal Supreme Court (BGH), 18 October 1967, 48 BGHZ 327 (at 330); In its referral to the Court of Justice of the European Union of 17 December 2009 - Neurale Vorläuferzellen, the German BGH with reference to the established German case law and doctrine emphasizes that the fundamental principles of the legal order ("tragende Grundsätze der Rechtsordnung") are composed of the basics of the state, social and economic life in the Federal Republic of Germany and the essential constitutional principles, which make up the "set in stone" ("unverrückbar") basis of the state and social life (2010 GRUR Int. 236, at 239); cf. also (Moufang, 1991: Art. 53 EPC, marginal notes 30-31), who emphasizes that also the fundamental principles of international treaties by which the Contracting States to the EPC are bound, such as the European Convention on Human Rights (ECHR), are to be viewed as ordre public; (Gervais, 2003: 222), observes in this context: "While public order may be defined as the maintenance of public safety, ordre public concerns the fundamentals from which one cannot derogate without endangering the institutions of a given society."

${ }^{34}$ Cf. also (Straus, 2013: 22-23).

35 Cf. (Correa, 2007: 291; Pires de Carvalho, 2010: 298) ('Exclusion from patentability must be preceded by exclusion from commercial exploitation, where exclusion from commercial exploitation is necessary to protect ordre public and morality.'); (Straus, 1996: 182); implicitly also (Gervais, 2003: 223).

${ }^{36}$ Annex 1A to the Marrakesh Agreement establishing the World Trade Organization.

${ }^{37}$ Ibidem.

${ }^{38}$ Ibidem at p. 210.

${ }^{39}$ From patentability [J.S.].

${ }^{40}$ Cf. also (Correa, 2007: 291; Gervais, 2003: 223). 
J. Straus: Medicine Between Ethics and Scientific Progress: How Much Ethics Needs Medicine, how much ethics can it afford?Some considerations from patent law perspectives

${ }^{41}$ Cf. (Gervais, 2003: 223).

${ }^{42}$ Cf. specifically (Rogge, 1998:303).

${ }^{43}$ See also (Straus, 1995: 930-931).

${ }^{44}$ Cf. (Pires de Carvalho, 2010: 300; Straus, 1995).

45 As argued by the Technical Board of Appeal of the European Patent Office (EPO) in a decision of 21 February 1995 (1995 OJ EPO 545 - Plant Cells/Plant Genetic Systems).

${ }^{46}$ Cf. (Straus, 1995); and the critics of R. Rogge (Rogge, 1998).

47 (Rogge, 1998: 223).

${ }^{48}$ Referring to the decision T 356/93 of the Board of Appeal of the EPO of 21 February 1995 (1995 OJ EPO 545 - Plant Cells/Plant Genetic Systems), and observing that the principles developed therein on the morality notion were not to be viewed as internationally accepted (op.cit., p. 288). In the referred decision, the Technical Board of Appeal held: "The concept of morality is related to the belief that some behaviour is right and acceptable whereas other behaviour is wrong, this belief being founded on the totality of the accepted norms which are deeply rooted in a particular culture. For the purposes of the EPC, the culture in question is the culture inherent in European society and civilisation. Accordingly, under Article 53(a) EPC, inventions the exploitation of which is not in conformity with the conventionally accepted standards of conduct pertaining to this culture are to be excluded from patentability as being contrary to morality." (1995 OJ EPO 557),

${ }^{49}$ In this context Correa refers to (Pollaud-Dulian, 1997: 166).

${ }^{50}$ (Correa, 2007: 288).

51 1998 GRUR 304.

${ }^{52}$ R. Rogge, 1998 GRUR 305, with further references.

${ }^{53} \mathrm{Cf}$. for more (Straus, op.cit., footnote 45, pp. 28-30

54 Article 5 (1) of the Directive is in this respect complemented by Article 5 (2), which requires that an element isolated from the human body or otherwise produced by means of a technical process, may constitute a patentable invention, even if the structure of that element is identical to that of a natural element. Under this provision the envisaged protection covers only the result of inventive scientific or technical work, and extends to biological data existing in their natural state in human beings only where necessary for the achievement and exploration of a particular industrial application (European Court of Justice - ECJ judgement of 9 October 2001, in Case C-377/98 - Kingdom of the Netherlands, supported by Italian Republic and by Kingdom of Norway v. European Parliament and Council of the European Union, supported by Commission of the European Communities [2001] ECR I - 7079, p. 75; Judgement of 16 July 2005 - in Case C-456/03 Commission of the European Community v. Italian Republic, [2005] ECR I-5335 at p. 69). Only inventions which combine a natural element with a technical process enabling it to be isolated or produced for an industrial application can be the subject of a patent application. Consequently, an element of the human body may be part of a product which is patentable but it may not, in its natural environment be appropriated (ECJ Judgement in case C-377/98 at p. 72 and 73; and ECJ in Case C-456/03 at p. 67).

${ }^{55}$ ECJ Judgment in Case C-377/98 at p. 70.

${ }^{56} \mathrm{ECJ}$ in Case C-377/98 at p. 37 and 38.

${ }^{57} \mathrm{ECJ}$ in Case C-456/03 at p. 78.

582010 GRUR Int. 236 - Neurale Vorläuferzellen.

59 Judgment of the Court (Grand Chamber) of 18 October 2011 in the Case C-34/10 Oliver Brüstle v. Greenpeace e.V. 
(a) Does it include all stages of the development of human life, beginning with the fertilization of the ovum, or must further requirements, such as the attainment of a certain stage of development, be satisfied?

(b) Are the following organisms also included:

- fertilized human ova into which a cell nucleus from a mature human cell has been transplanted;

- fertilized human ova whose division and further development have been stimulated by parthenogenesis?

(c) Are stem cells obtained from human embryos at the blastocyst stage also included" (reproduced in O. Brüstle at 23).

${ }^{61}$ Ibidem.

${ }^{62}$ Cf. Neurale Vorläuferzelle, 2010 GRUR Int. at p. 62 (cf. J. Straus, Comment, 2011 GRUR Int. 1048 ss.).

${ }^{63}$ Cf., for instance, B. Rigby, A Ban on Stem Cell Patents in Europe?, 12 World Intellectual Property Report BNA 50 ss. (2011); A. Hübel, Patentability of Pluripotent Stem Cells Unlikely Although they are not Considered as Embryo, Mitteilungen der deutschen Patentanwälte 494 ss. (2011); (Moran, 2011:1057; Taupitz, 2012: 1; Straus, 2011: 1048; Plomer, 2011; Paton and Denoon, 2011: 590).

${ }^{64}$ In the case Evans $v$. United Kingdom, ECHR explicitly found: "... in the absence of any European consensus on the scientific and legal definition of the beginning of life, the issue of when the right to life begins comes within the margin of appreciation which the Court generally considers that States should enjoy in this sphere. Under English law... an embryo does not have independent rights or interests and cannot claim - or have claimed in its behalf - a right to life under article 2" (Judgement of 7 March 2006, application No. 6339/05, confirmed by decision of the Grand Chamber of 10 April 2007 (No. 46). Cf. (Plomer, 2009: 222-223).

${ }^{65}$ Evans at p. 26. The Court emphasized that, "Although, the definition of human embryo is a very sensitive social issue in many Member States, marked by their multiple traditions and value system, the Court is not called upon, by the present order for reference, to broach question of a medical or ethical nature, but must restrict itself to a legal interpretation of the relevant provisions of the Directive." (Evans at p. 30).

${ }^{66}$ Evans at p. 18.

${ }^{67}$ Mr. Willy Rothley, Member of the European Parliament and the competent reporter for the Directive in the European Parliament, stated in the context of interest: "In relation to the use of embryos, the Council has set some limitations: They are not to be used for industrial or commercial purposes. But I would only ask you to remember that this was done with the United Kingdom in mind. We cannot as European legislators decree that something which does not contravene the underlying legal principles of all Member States is in contravention of public order, and we cannot brand something that we do not jointly regard as abhorrent as a contravention of common decency. That is not acceptable! It is only exemplary and in any case, that is to say, other ways of using embryos may be investigated with the proviso that they do not contravene public order and common decency for other reasons." Quoted from (Porter, 2009: 22).

${ }^{68}$ Evans at p. 34 and 35.

${ }^{69}$ Ibidem at p. 36.

${ }^{70}$ Ibidem at p. 43.

${ }^{71}$ Ibidem at p. 46.

${ }^{72}$ Ibidem at p. 49. 
J. Straus: Medicine Between Ethics and Scientific Progress: How Much Ethics Needs Medicine, how much ethics can it afford?Some considerations from patent law perspectives

${ }^{73}$ Ibidem at p. 50.

${ }^{74}$ In the Case C-377/98, ECJ explicitly emphasized: "Reliance on this fundamental right [human integrity - J.S.] is, however, clearly misplaced as against a directive which concerns only the grant of patents and whose scope does not therefore extend to activities before and after that grant, whether they involve research or the use of the patented product." (p. 79).

75 OJ 2004 No. L 102, p. 48 of 7 April 2004.

${ }^{76}$ OJ 2007 No. L 324, p. 121 of 10 December 2007.

${ }^{77}$ Cf. for more (Plomer, 2011: 173) Towards Systemic Legal Conflicts: Article 6 (2) (c) of the EU Directive on Biotechnological Inventions, in A. Plomer/P. Torremans (eds.), Embryonic Stem Cell Patents - European Law and Ethics, Oxford, pp. 173 ss. (2009) Aurora Plomer observes in this context: "In general, hESC-based products may be made on an industrial scale and commercialized in Europe, irrespective of whether the activities involved destruction of human embryos. A broad exclusionary construction, if correct, would therefore lead to the paradox contradiction that applicants engaging in activities which are lawful and morally permissible in EU Member States are denied patent protection on the related invention on the basis that the practice of invention is deemed immoral from within patent law." (at p. 180).

${ }^{78}$ Millipor catalogue No. SCR055-ENStem- ${ }^{\mathrm{TM}}$ Human Neural Progenitor Expansion Kit. The kit components are inter alia, 1.>1 x $10^{6}$ viable ENStem-A ${ }^{\mathrm{TM}}$ Human Neural Progenitor Cells (Part. No. SCC003) derived from NIH approved H9 human embryonic stem cells, cryopreserved. Store in liquid nitrogen. Characterization of cells: each lot of ENStem- $\mathrm{A}^{\mathrm{TM}}$ Human Neural Progenitor Cells has been validated for high levels of expression of Nestin and Sox II, and low level expression of Oct-4. The ability of ENStem$\mathrm{A}^{\mathrm{TM}}$ Cells to differentiate into multiple neuronal phenotypes and maintain a normal caryotype after multiple passages has been verified... The cells have been confirmed to be negative for microplasms (cf. Millipor Product Selection Guide - Neuroscience, Antibodies, Proteins, Kits and other reagents (12/12/2007/SCC03/VC/LR/CP)).

${ }^{79}$ Cf. (O. Brüstle, p. 48.

${ }^{80}$ In this regard reference may be made to the Opinion of Advocate General Cruz Villalón of 17.07.2014 in International Stem Cell Corporation v. Comptroller General of Patents (Case C-364/13), referred to CJEU by Order of 17.04.2013 by High Court of Justice of England and Wales, requesting an answer to the following question:

"Are unfertilised human ova whose division and further development have been stimulated by parthenogenesis, and which, in contrast to fertilised ova, contain only pluripotent cells and are incapable of developing into human beings, included in the term "human embryos" in Article 6(2)(c) of Directive 98/44 on the Legal Protection of Biotechnological Inventions?".

Attorney General Villalón, entirely concurs with the Brüstle Judgment of CJEU, does not address at all the TRIPS compliance and even opines:

"This means that in the context of the task confided to each Member State to determine which inventions are not patentable in light of consideration of ordre public and morality, the Directive establishes a nucleus of non-patentability, a kind of 'no-go zone' that is common for all Member States as an expression of what has to be considered unpatentable in any case. Consequently, if parthenotes are not included in the notion of human embryos in the sense of the Directive this would not imply that Member States could not prohibit their patentability on the basis of other considerations of ordre public or morality, all the while respecting that the notion of human embryo does not extend to parthenotes." (No. 43) (http://www.bailii.org/eu/cases/EUECJ/2014/C36413_O.html). 
${ }^{81}$ See also the comment of J. Straus (Straus, 2011).

82 Draft Opinion of 22 May 2012 (PA1902069EN.doc) and the Opinion of 18 September 2012 (AD1913037EN.doc).

\section{References}

Business Wire (2009): BioSante Pharmaceuticals and Cell Genesys Announce September 30, 2009 Special Stockholders Meetings to Approve Merger, BusinessWire, (September, 3, 2009) (San Francisco: Business Wire), available at: http://www.businesswire.com/news/home/20090903005210/

en/BioSante-Pharmaceuticals-Cell-Genesys-Announce-September-30 (October 11, 2015).

Aggarwal, S. (2007) What's fueling the biotech engine?, Nature Biotechnology, 25, pp. 1097-1104, doi: 10.1038/nbt1007-1097.

Aggarwal, S. (2014) What's fueling the biotech engine - 2012 to 2013, Nature Biotechnology, 32(1), pp. 32-39. doi: 10.1038/nbt.2794.

ALLEA (2012) ALLEA Statement on Patentability of Inventions Involving Human Embryonic Pluripotent Stem Cells in Europe of May 2011 and the Judgment of the Court of European Communities (Grand Chamber) of 18 October 2011 in Case C34/10 of September 2012 (Berlin: ALLEA), available at: http://www.allea.org/Content/ALLEA/2013_10_ALLEA-statement_stem-cells.pdf (March 6, 2015).

ALLEA (2013) ALLEA Statement on Patentability and Research Funding relating to embryonic Stem Cells (e-SCs) of October 2013 (Berlin: ALLEA), available at http://www.allea.org/Content/ALLEA/2013_10_ALLEA-statement_stem-cells.pdf (March 6, 2015).

Beier, F. K. \& Straus, J. (1986) Genetic Engineering and Industrial Property, Industrial Property, 25, p. 447.

Benkard (Melullis K.-J.) (2012) EPÜ - Europäisches Patentübereinkommen, 2nd ed. (Munich: C. H. Beck).

Berg, P. (2008) Meetings that changed the world: Asilomar 1975: DNA modification secured, Nature, 455, pp. 290-291, available at: http://openwetware.org/images/5/56/Asilomar1975_Nature08.pdf (March 8, 2015).

Berg, P., Baltimore, D., Brenner S., Roblin, R. O. \& Singer M. F. (1975) Summary Statement of the Asilomar Conference on recombinant DNA molecules, Proceedings of the National Academy of Sciences of the United States of America, 72(6), pp. 19811984, available at: http://www.ncbi.nlm.nih.gov/pmc/articles/PMC432675/ (March 12, 2015).

Bock, G., Cohen, D., Goode, J., Novartis Foundation., \& Symposium on From Genome to Therapy: Integrating New Technologies with Drug Development (2000) From genome to therapy: Integrating new technologies with drug development (Chichester: Wiley).

The Free Library (2014) Chiron Files Infringement Suit in Japan Against Roche On HCV Patent (n.d.) (Huntingdon Valley: Farlex), available at: http://www.thefreelibrary.com/Chiron+Files+Infringement+Suit+in+Japan+Against+ Roche+On+HCV+Patent.-a020497328 (March 20, 2015).

Caskey, C. T. (2007) The drug development crisis: Efficiency and safety, Annual Review of Medicine, 58, pp. 1-16, doi: 10.1146/annurev.med.58.042705.124037. 
J. Straus: Medicine Between Ethics and Scientific Progress: How Much Ethics Needs Medicine, how much ethics can it afford?Some considerations from patent law perspectives

Cohen, W. W. \& Merrill, S. A. (2003) Introduction, In: Cohen, W. W. \& Merrill, S. A. (eds.) Patents in the knowledge-based economy (Washington D.C.: National Academies Press).

Correa, C. M. (2007) Trade Related Aspects of Intellectual Property Rights - A Commentary on the TRIPS Agreement (Oxford: Oxford University Press).

Di Masi, J. A., Hansen, R. W. \& Grabowski, G. (2003) The price of innovation: New estimates of drug development costs, Journal of Health Economics, 22(2), pp. 151185, doi: 10.1016/S0167-6296(02)00126-1.

Drabiak-Syed, K. (2013) New president, new human embryonic stem cell research policy: Comparative international perspectives and embryonic stem cell research laws in France, Biotechnology Law Report, 32(6), pp. 349-356, doi: 10.1089/blr.2013.9865.

Gallagher, J. (2012) Gene therapy: Glybera approved by European Commission, BBC News Health (November 2, 2012), available at: http://www.bbc.com/news/health-20179561 (March 2, 2015).

German Federal Supreme Court (BGH), 18 October 1967, 48 BGHZ 327 (at 330).

Gervais, D. (2003) The TRIPS Agreement: Drafting History and Analysis, 2nd ed. (London: Sweet and Maxwell).

Hill, A. \& Cooke, G. (2014) Hepatitis C can be cured globally, but at what cost?, Science, 345(6193), pp. 141-142, doi: 10.1126/science.1257737.

Holden, C. \& Vogel, G. (2008) A seismic shift for stem cell research, Science, 319(5863), pp. 560-562, doi: 10.1126/science.319.5863.560.

Hübel, A (2011) Patentability of Pluripotent Stem Cells Unlikely Although they are not Considered as Embryo, Mitteilungen der deutschen Patentanwälte 494 ss.

Straus, J. (2000a) Is patent law getting out of hands? Misconceptions in the outcry against a decision of the European Patent Office, EPO Gazette, Special Edition, May 2000, pp. $8-11$.

Johnson, I. S. (1983) Human insulin from recombinant DNA technology, Science, 219(4585), pp. 632-637.

Kaiser, J. (2007) Death prompts a review of gene therapy vector, Science, 317(5838), pp. 580 (August, 3, 2007), doi: 10.1126/science.317.5838.580.

Kling, J. (2012) Fresh from the biotech pipeline - 2011, Nature Biotechnology, 30(2), pp. 128-131, doi:10.1038/nbt.2111.

Landes, W. M. \& Posner, R. A. (2003) The economic structure of intellectual property law (London: Belknap Press).

Ledford, H. (2007) Death in gene therapy trials raises questions about private IRBs, Nature Biotechnology, 25(10), pp. 1067, doi:10.1038/nbt1007-1067.

Mansfield, E. (1986) Patents and innovation: An empirical study, Management Science,. 32(2), pp. 173-181.

Moran, N. (2011) European Court Bans Embryonic Stem Cell Patents, Nature Biotechnology, 29(12), 1057-1059, doi:10.1038/nbt1211-1057.

Moran, N. (2012) First gene therapy nears landmark European market authorization, Nature Biotechnology, 30, 807-809, doi: 10.1038/nbt0912-807.

Paton, M. \& Denoon, A. (2011) The Ramifications of the Advocate General's Opinion in the Oliver Brüstle case, E.I.P.R., 590 ss.

Pires de Carvalho, N. (2010) The TRIPS Regime of Patents Rights, 3rd ed. (The Hague: Kluwer Law International).

Plomer, A. (2009) Human Dignity, Human Rights and Article 6(1) of the EU Directive on Biotechnological Inventions, In: Plomer, A \& Torremans, P. (eds.) Embryonic Stem Cell Patents - European Law and Ethics (Oxford: Oxford University Press). 
Plomer, A. (2009) Towards Systemic Legal Conflicts: Article 6(2) (c) of the EU Directive on Biotechnological Inventions, In: Plomer, A \& Torremans, P. (eds.) Embryonic Stem Cell Patents - European Law and Ethics (Oxford: Oxford University Press).

Plomer, A. (2011) EU Ban on Stem Cell Patents is a Threat Both to Science and the Rule of Law, The Guardian (December 12, 2011), available at: http://www.guardian.co.uk/science/blog/2011/dec/12/eu-ban-stem-cell-patents (March 18, 2015).

Pollaud-Dulian F. (1997) La Brevetabilité des Invention, Etude Comparative de Jurisprudence, France-OEB (Paris: Le Droit des Affaires, LexisNexis).

Porter, G. (2009) The Drafting History of the European Biotechnology Directive, In: Plomer, A \& Torremans, P. (eds.) Embryonic Stem Cell Patents - European Law and Ethics (Oxford: Oxford University Press)

Moufang, R. (1991) Europäisches Patentübereinkommen - Münchner Gemeinschaftskommentar, 15th issue, Art. 53 EPC, marginal notes 30-31 (KölnBerlin-Bonn-München: Heymanns Carl).

Rigby, B. (2011) A Ban on Stem Cell Patents in Europe?, 12 World Intellectual Property Report BNA (Arlington: Bloomberg BNA).

Rogge, R. (1998) Patente auf genetische Informationen im Lichte der öffentlichen Ordnung und der guten Sitten, 1998 GRUR 303ss. (at 303).

Seymour, L. W. \& Thrasher A. J. (2012) Gene therapy matures in the clinic, Nature Biotechnology, 30(7), pp. 588-593, doi:10.1038/nbt.2290.

Stollorz, V. (2014) Hepatitis C - Dramatischer Durchbruch, Frankfurter Allgemeine Zeitung (July 29, 2014), available at: http://www.faz.net/aktuell/wissen/medizin/neues-medikament-soll-hepatitis-c-heilen13067661-p2.html (March 22, 2015).

Straus, J. (1996b) Patentrechtliche Probleme der Gentherapie, 1996 GRUR, 10 ss.

Straus, J. (1985) Industrial property protection of Biotechnological inventions, Analysis of certain basic issues, World Intellectual Property Organization, doc. IPD/2867I, Geneva 1985, pp. 22-42.

Straus, J. (1995) Patenting Human Genes in Europe - Past Developments and Prospects for the Future, IIC - International Review of Industrial Property and Copyright Law, 26(6), pp. 920-950.

Straus, J. (1996a) Implications of the TRIPS Agreement in the Field of Patent Law, In: Beier, F. K. \& Schricker, G. (eds.) From GATT to TRIPS - The Agreement on Trade Related Aspects of Intellectual Property Rights (Weinheim and New York: Wiley$\mathrm{VCH})$.

Straus, J. (2000b) Patenting genes and gene therapy - Legal and ethical aspects, In: Bock, G. R., Cohen, D. \& Goode, J. A. (eds.) From genome to therapy: Integrating new technologies with drug development (Chichester, New York, Weinheim, Brisbane, Singapore, Toronto: Wiley).

Straus, J. (2001) Intellectual Property Rights: Ethical Aspects, In: Smelser, N. J. \& Baltes, P. B. (eds.) International Encyclopaedia of the Social \& Behavioural Sciences (Amsterdam, Paris, New York, Oxford, Shannon, Singapore, Tokyo: Elsevier).

Straus, J. (2012) A Marriage of Convenience: World Economy and Intellectual Property From 1990 to 2012, AIPLA Quarterly Journal, 40(4), 633-683.

Straus, J. (2013) Ordre public and morality issues in patent eligibility, In: Takenaka, T. (ed.), Intellectual property in common law and civil law (Cheltenham (UK), Northampton: Edward Elgar), doi: 10.4337/9780857934376.00009. 
J. Straus: Medicine Between Ethics and Scientific Progress: How Much Ethics Needs Medicine, how much ethics can it afford?Some considerations from patent law perspectives

Ward (2014) Bitter pills - The high cost of a new hepatitis treatment: Is prompting the debate that most alarms industry: Whether to curb the US free market in drugs, Financial Times, August 1, 2014, p. 5.

Whalen, J. (2012) Gene-therapy approval marks major milestone, Wall Street Journal

(November 2, 2012), available at: http://online.wsj.com/news/articles/SB100014240529702037076045780950919408715 24 (March 20, 2015). 